\title{
有機ビラジカル分子薄膜の電子構造
}

\author{
金井 要*1·古池 晴信*1·水津 理恵 $* 2$
}

阿波賀邦夫*2 ·間瀬 一彦*3 · 久保 孝史*4

\section{Electronic Structure of Organic Biradical Molecular Films}

\author{
Kaname KANAI*1, Harunobu KOIKE*1, Rie SUIZU*2, \\ Kunio AWAGA*2, Kazuhiko Mase*3 and Takashi KUBO*4
}

\begin{abstract}
*1Department of Physics, Faculty of Science and Technology, Tokyo University of Science, 2641 Yamazaki, Noda-shi, Chiba 278-8510, Japan *2Department of Chemistry, Graduate School of Science, Nagoya University, Furo-cho, Chikusa-ku, Nagoya-shi, Aichi 464-8602, Japan ${ }^{* 3}$ Institute of Materials Structure Science, KEK, 1-1 Oho, Tsukuba-shi, Ibaraki 305-0801, Japan

${ }^{* 4}$ Department of Chemistry, Graduate School of Science, Osaka University, 1-1 Machikaneyama, Toyonaka-shi, Osaka 560-0043, Japan
\end{abstract}

(Received March 14, 2012, Accepted October 14, 2012)

\begin{abstract}
Most research in the field of organic electronics has focused on $\pi$-conjugated molecules with a closed-shell configuration, which accommodate their $\pi$-electrons in only bonding orbitals and are consequently quite stable. In general, closed-shell molecules have wide energy gaps, and they have significantly weaker intermolecular interactions. In contrast, recently organic biradicals have attracted considerable attention, owing to their interesting physical properties, e.g., a small energy gap and strong intermolecular interactions. Organic biradical molecules are composed of a pair of organic radicals that possess an open-shell configuration. Owing to their radical nature, biradical molecules exhibit unusual physical properties such as those listed above. This article is a review of our recent study on the electronic structure of two different types of organic biradical molecules that have potential as new materials for manufacturing electronic devices. In particular, our results show that organic biradicals are expected to form a new class of materials for use in organic electronics as new building blocks for highly ordered organic semiconducting films with wide energy band dispersion widths and a narrow energy gap.
\end{abstract}

\section{1. はじめに}

近年, 有機電界発光素子や, 有機トランジスタ, また有機 太陽電池などの有機デバイスの研究が盛んに行われている. これらのデバイスは, 基本的に有機半導体と呼ばれる有機分 子の固体薄膜を活性層とした構造を持っている．これまでに 研究が行われてきたほとんどの有機半導体分子は，化学的に 安定な閉殼構造を持っている. 一方で, 不対電子を持つ開殼 の有機分子を有機ラジカルと呼ぶが，有機ラジカル分子の中 にも半導体的な電気特性を示すものが知られている1-7). 本 来なら, 有機ラジカルの固体中では, 不対電子がキャリアと なり，金属的となる可能性を持っているが，電子相関や電 子-格子相互作用によって電子が自由に動く事が妨げられる ため半導体に留まっているものと考えられる。これまで, 多 くの有機ラジカル分子は, 基礎的な磁性研究の対象ではあっ たが，その化学的な不安定さもあり，有機エレクトロニクス の材料として注目されることはほとんどなかった.

一方， $\pi$ 共役系の両端に有機ラジカルを配置した構造を持 つ分子を有機ビラジカル分子と呼ぶ. 有機ビラジカル分子の 中には, 有機ラジカルに由来する興味深い特性を示すものも あり, 近年, 一部の有機ビラジカル分子が新しい有機エレク

*1 東京理科大学理工学部物理学科（二278-8510 千葉県野田市 山崎2641)

*2 名古屋大学大学院理学研究科（干464-8602 愛知県名古屋市 千種区不老町)

*3 高エネルギー加速器研究機構物質構造科学研究所 (テ3050801 茨城県つくば市大穂 1-1)

*4 大阪大学大学院理学研究科 (T560-0043 大阪府豊中市待兼 山町 1-1)
トロニクス材料として注目されるようになってきた．本稿で は, その中でも, 性格の異なる二つの有機ビラジカル分子を 取り上げ, 分子自体の電子状態々, その高秩序固体薄膜の電 子状態の最近の研究成果について解説する. 有機ビラジカル 分子は, 有機ラジカル分子と異なり, 比較的, 化学的に安定 であるため, 有機エレクトロニクスに打利しい光・電子 機能材料として非常に有力な候補と成り得る.したがって, 有機ビラジカル分子と, その固体の電子状態を知ることは, 基礎研究的な観点に加え, 有機エレクトロニクスの新しい材 料設計の観点からも興味深い.

\section{2. 有機ビラジカル分子 : $\mathrm{Ph}_{2}$-IDPL と BDTDA}

有機ビラジカル分子は, 分子が閉殼のケクレ型共鳴構造 （共役系を一重結合と二重結合で交互に記述した構造）をと る場合と, とらない場合に分類することができる. 前者は共 鳴構造をとることで安定化する.この場合, 通常は分子内に 不対電子は存在せず, 閉殼構造のスピン一重項が基底状態と なる. 一方, 後者の非ケクレ型ビラジカル分子は, さらに disjoint 型と non-disjoint 型に分類される. disjoint 型は分子 両端に配置されている有機ラジカル由来の二つの SOMO (singly occupied molecular orbital) が直交しているものであ り, 不対電子由来のスピン間の磁気的相互作用は小さい。し たがって, 磁気的には, 基底状態において一重項と三重項が ほぼ縮退している。一方で, non-disjoint 型は二つの SOMO が空間的な重なりを持つものであり, 不対電子間には強磁性 的な相互作用がはたらく.

Fig. 1 に, 本稿で取り上げる有機ビラジカル分子 $\mathrm{Ph}_{2}-\mathrm{IDPL}$ (8,16-diphenyl-s-indaceno[1,2,3-cd:5,6,7-c' $\left.d^{\prime}\right]$ diphenalene $)^{8)}$ 


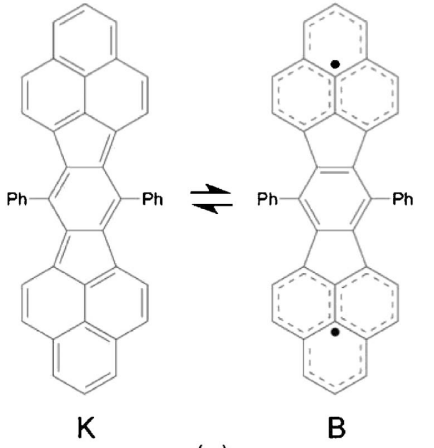

(a)

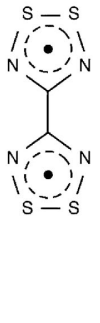

(b)
Fig. 1 (a) Resonance structure of $\mathrm{Ph}_{2}$-IDPL. $\mathrm{K}$ and $\mathrm{B}$ denote quinoidal Kekulé and biradical structures, respectively. (b) Molecular structure of BDTDA.

と BDTDA $\left(4,4^{\prime} \text {-bis }(1,2,3,5 \text {-dithiadiazolyl })\right)^{9)}$ の分子構造を 示した. $\mathrm{Ph}_{2}$-IDPL は, フェナレニルラジカルをパラベンゾ キノンでつなげた構造, BDTDA はジチアジアゾリルラジ カルをつなげた構造を持っている. 上記の分類では, $\mathrm{Ph}_{2}-$ IDPL はケクレ型の一重項ビラジカル，BDTDA は非ケクレ 型の disjoint 型ビラジカルに分類される. 後述するように, $\mathrm{Ph}_{2}$-IDPL と BDTDA は固体薄膜の形態や電子状態も互い に大きく異なるが，両者に共通する性質は非常に強い分子間 相互作用を持つという点である.この有機ビラジカル分子特 有の強い分子間力は，有機ビラジカル分子が，これまでにな い新しい有機エレクトロニクス材料となる可能性を持ってい る. 一般の有機半導体分子は，一般に閉殼構造をとってお り, その薄膜の主な凝集力は分散力（ファンデルワールスカ とも呼ばれる) である. 従って, 分子間の波動関数の重なり は小さく, 結晶や固体薄膜に扔いて分散幅の広いエネルギー バンドが形成されることはほとんどない，例えば，ポリアセ ンなどの単結晶でさえ, $\pi$ バンドの分散幅は数十から 100 $\mathrm{meV}$ 程度である ${ }^{11)}$. たた, 結晶性の低い有機半導体薄膜の 場合，それぞれの分子の分子軌道は各サイトに局在してお り, キャリア伝導は「小さいポーラロン」のホッピングによ ると考えられている. そのため, 有機半導体における伝導入 カニズムは, 従来の電子デバイスに抢ける無機半導体と本質 的に異なる. 一方, 有機ビラジカル分子の固体中では, 強い 分子間引力によって, 分子間で大きな分子波動関数の重なり を持ち，軌道間相互作用を介して結合性，反結合性軌道が形 成されるため, 無機半導体と同様のバンド伝導が期待され る.したがって, 例えば, 有機ビラジカル分子の結晶性薄膜 を作ることができれば，従来の有機半導体薄膜を用いたもの よりも，桁違いに高い移動度をもつ電界効果トランジスタや フィルファクターの高い太陽電池など，新しい有機デバイス を実現することができる.

\section{3. $\mathrm{Ph}_{2}-\mathrm{IDPL}$ 結晶性薄膜の作製と電子状態}

$\mathrm{Ph}_{2}$-IDPL は大阪大学の久保, 中筋らによって合成された ケクレ型の有機ビラジカル分子であり, 基底状態はスピン一 重項となっている. Fig. 2 に示したように, $\mathrm{Ph}_{2}$-IDPL は結 晶中で, 分子の一部を重衫るようにしてスタックした構造
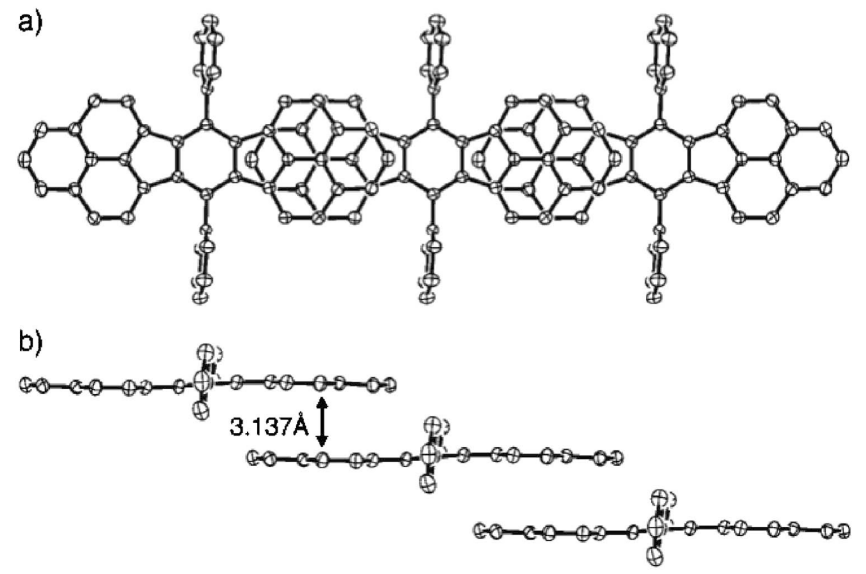

Fig. 2 Crystal structure of $\mathrm{Ph}_{2}$-IDPL, which is cited from the literature ${ }^{8)}$. Hydrogen atoms and the solvated chlorobenzene molecule are omitted for clarity.

（以下，この構造をスリップスタックと呼ぶ）をとっている. 通常, 分子間相互作用が強いラジカル, ビラジカル分子の場 合には，分子は固体中で容易に二量体化してしまい，系は 0 次元化してしまう. $\mathrm{Ph}_{2}$-IDPLは，その二量体化を避けるた めに，二つのフェニル基が導入されて打り，その立体障害に よってスリップスタック構造をとることができる.スリップ スタックした分子は，軌道間相互作用により強い共有結合性 を持ち, 分子間距離はきわめて短く, ファンデルワールス半 径の和の約 $90 \%$ となる. 通常, 閉殼の分子間には, このよ うな非常に強い分子間力がはたらくことはない．通常の閉殸 分子の場合に二分子のフロンティア軌道間の相互作用を考元 ると, HOMO（最高被占有分子軌道）間の二軌道四電子相 互作用は，一般的に斥力的にはたらき，結合性軌道の形成を 妨げる. 一方で, ビラジカル性を持つと言っても, やはり閉 殼である $\mathrm{Ph}_{2}-$ IDPL が，なぜ結合性軌道を形成することが できるのだろうか． $\mathrm{Ph}_{2}$-IDPLの基底状態は，LUMO（最 低非占有分子軌道）を二電子が占有した，二電子励起状態と HOMO が二電子によって占有された状態の配置間相互作用 によって記述される。すなわち, 基底状態では, HOMO の 平均占有率が，スピンの縮重度 2 を下回り, LUMO の平均 占有率が有限となるため, 厳密には二軌道四電子相互作用々 はならず，結合性軌道を形成することによる利得が生じるの である。

もし，薄膜中に扔いても，共有結合による $\mathrm{Ph}_{2}-$ IDPL 分 子鎖を形成されれば，分子鎖方向にはバンド伝導による高い 移動度が実現することが期待される．実際に， $\mathrm{Ph}_{2}$-IDPL 結 晶の分子鎖方向の電気伝導度は炭化水素からなる有機物質の なかで，最も高い值を示す8)

ここでは，まず，どのようにして $\mathrm{Ph}_{2}$-IDPL 分子の結晶 性薄膜を作製するかについて紹介する. Fig. 3 に $\mathrm{Ph}_{2}$-IDPL 分子の単分子層をグラファイト基板上に成長させたときの STM 画像を示す．分子が一方向に整列して並んでいるのが 分かる，一見， $\mathrm{Ph}_{2}$-IDPL 分子が結晶中と同様に，互いに久 リップスタックした分子鎖を形成しているように思われる が，画像の解析からは，分子は基板に対して，格子定数が整 
合した擬エピタキシャル成長していることが分かった。つま り，分子間力よりも基板とのファンデルワールス力の利得が 大きく，分子はほぼ孤立した状態で吸着している．この実験 結果は, $\mathrm{Ph}_{2}$-IDPL 分子が非常に強い分子間相互作用を持つ にも関わらず，それを活かした結晶化がうまく起こらないこ とを示している12,13). 実は, $\mathrm{Ph}_{2}$-IDPL は分子面と垂直な方 向には強い分子間相互作用を持つのだが，分子面と平行な方 向にはフェニル基による立体障害があり，分子間力は非常に 弱い. つまり, 分子間力は著しく一次元的である. つまり, この事実は, 分子間力をうまく発揮して薄膜を形成するため には，仮に一方向に強い分子間力を持つ場合でも，ある程度 その他の方向の分子間力もはたらき，三次元的な分子間力を 持つ事が重要であることを示している．後述するが，BDTDA は，このような分子面と平行な方向の二次元的な分子間 相互作用を持つために, どのような基板の上でも, 真空蒸着 によって容易く結晶性の薄膜を形成する事ができる.

そこで, 特有の強い分子間相互作用を活かして, $\mathrm{Ph}_{2}-$ IDPL 薄膜の結晶化を促進するために，我々は“ガス中蒸発 法”と言う方法を用いた。この方法は，有機単結晶の作製に 用いられるトレインサブリメーション法（窒素などの不活性 気体気流下で有機試料を昇華させ精製する手法）に似た方法 である.ガス中蒸発法では, 試料を不活性気体中で昇華させ ることによって，基板上に到達した分子の平均自由行程が極 端に短くなることで結晶核の形成を促進し，薄膜の結晶化を

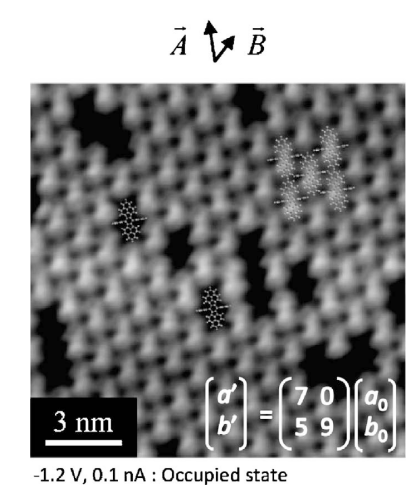

Fig. 3 STM image of $\mathrm{Ph}_{2}$-IDPL monolayer on graphite ${ }^{13,14)}$. The measurement conditions were $V_{\mathrm{S}}=-1.2 \mathrm{~V}$ and $I=0.1$ nA. Voltage $V_{\mathrm{S}}$ refers to the sample voltage with respect to the tip.
促す方法である. Fig. 4 に様々な圧力の窒素雾囲気中で $\mathrm{SiO}_{2}$ 基板上に作製した $\mathrm{Ph}_{2}-\mathrm{IDPL}$ 薄膜の可視紫外吸収 (UVVis）スペクトルを示す。結晶化の指標となる $7 \times 10^{3} \mathrm{~cm}^{-1}$ 付近の吸収ピーク (“crystal”) が， $5.4 \times 10^{2} \mathrm{~Pa}$ の圧力の窒 素中で作製した膜で最も強く現れていることが分かる．Fig. 5 (a)に示した X 線回折 $(\mathrm{XRD})$ の結果からも， $5 \times 10^{2} \mathrm{~Pa}$ の圧力の窒素中で作製した膜では明瞭な回折ピークが観測さ れ，Fig. 5(b)に示した原子間力顕微鏡 $(\mathrm{AFM})$ 像のように 粒径が約 $1 \mu \mathrm{m}$ 程度の結晶粒が集まった多結晶膜が成長して いることがわかる．結晶化の度合いは，窒素の圧力や基板の 種類にも依存することから，これらの条件を変えることで， コントロールすることができる. Fig. 6 に異なる結晶性を 持つ 3 種類の $\mathrm{Ph}_{2}-\mathrm{IDPL}$ 薄膜の光電子 (UPS) スペクトル を示した. UPS スペクトルは，一般に，物質のフェルミ準 位 $\left(E_{\mathrm{F}}\right)$ 以下エネルギーを持った一電子状態密度 (DOS) のレプリカを表す. Fig. 6 の一番下の UPS スペクトルは非 晶質の試料 $(\mathrm{A})$ ，中段は小さいサイズ（平均～ $10 \mathrm{~nm}$ ) の 結晶粒から成る試料（B)，上段は大きなサイズ（平均～1 $\mu \mathrm{m})$ の結晶粒から成る試料（C）の結果である. 試料の結 晶性が異なると, HOMO 付近の電子構造も大きく異なるこ とが分かる.この電子構造の違いを理解するために, Fig. 7 に $\mathrm{Ph}_{2}$-IDPLの会合体に対する分子軌道計算とバンド計算 から得られたDOSの結果を示す。図中の $N$ は会合体に含ま れる分子数を表している. まず，非晶質の試料に対するスぺ クトルは， $N=1$ ，つまり孤立した $\mathrm{Ph}_{2}-\mathrm{IDPL}$ 分子に対する DOS で良く説明される事がわかる. $1 \sim 3 \mathrm{eV}$ 程度に, 特徵

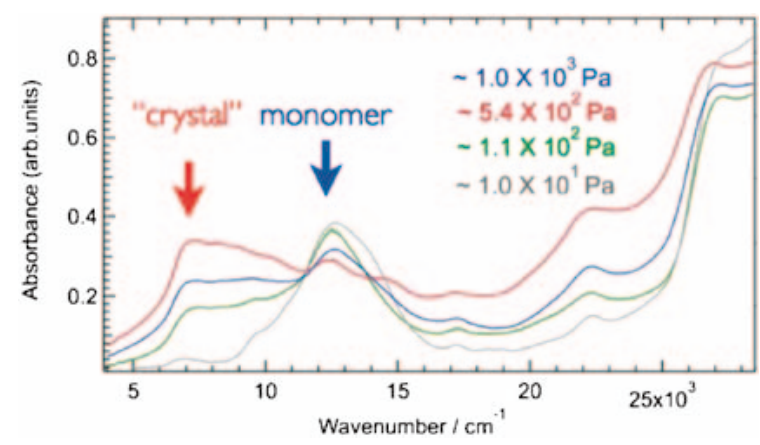

Fig. 4 UV-visible/near-IR absorption spectra of $\mathrm{Ph}_{2}-\mathrm{IDPL}$ films on glass substrate prepared by gas-deposition method.

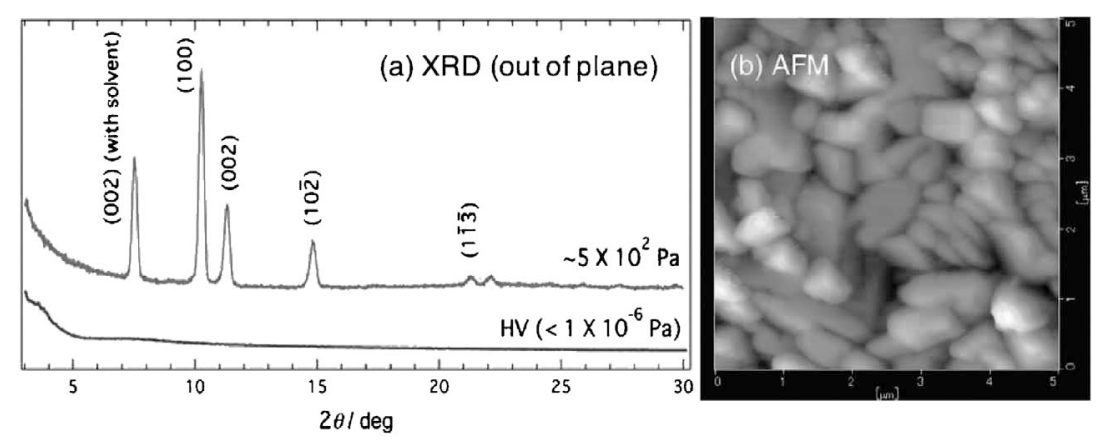

Fig. 5 (a) XRD spectra of $\mathrm{Ph}_{2}$-IDPL films prepared in vacuum $\left(<1 \times 10^{-6} \mathrm{~Pa}\right)$ and by gas-deposition method (partial pressure of nitrogene: $P_{\mathrm{N} 2}=0.5 \mathrm{kPa}$ ). (b) AFM images for $\mathrm{Ph}_{2}-\mathrm{IDPL}$ films prepared on HDMS: Si substrate by gas-deposition method. 


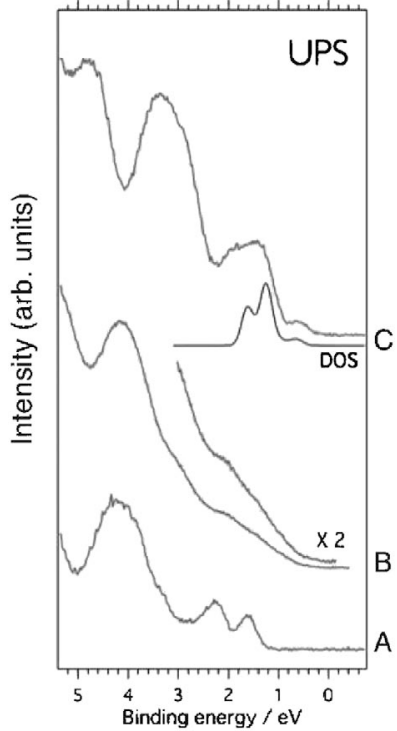

Fig. 6 UPS spectra of $\mathrm{Ph}_{2}$-IDPL films. The spectrum labeled "A" is obtained on the film in amorphous state. The spectra labeled " $\mathrm{B}$ " and " $\mathrm{C}$ " are obtained on the polycrystalline films with high and low crystallinity, respectively.

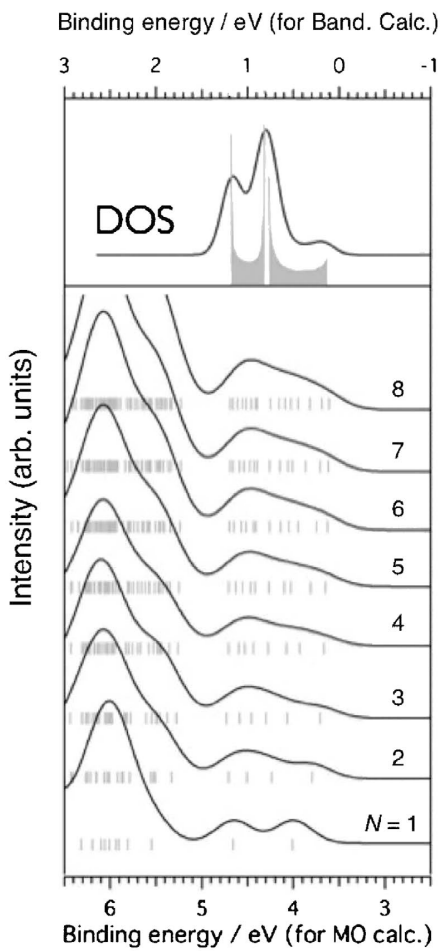

Fig. 7 Simulated UPS spectra of $\mathrm{Ph}_{2}$-IDPL oligomers. $N$ represents the molecular number in the oligomers. A spectrum labeled DOS represents the simulated DOS based on the band calculation.

的な 2 ピークが見られ，低いエネルギー側のピークが HOMO である. 次に, 小さい結晶粒からなる中段の UPS スペクトルを見ると，非晶質の試料のスペクトルとは異な り，非常に広がった形状をしている。“a”，“b”で示したエ ネルギーに構造が見られるが，いずれもピークとはならない 肩構造であり，そのエネルギーも非晶質で見られたピークと は異なっている。このような電子構造の変化は, まさに
$\mathrm{Ph}_{2}$-IDPL 分子間にはたらく強い分子間力に起因するもので ある. Fig. 7 の分子軌道計算を見ると，N=1 から順に分子 数が増加してゆくと, 分子間の共有結合的な軌道間相互作用 に伴って, 結合性, 反結合性軌道が形成され, 分子軌道が工 ネルギー的に広がって分布するようになる。この変化は $N$ $=1$ から 2,3 への増加に伴って最も顕著に DOS の形状に反 映されるが, $N=4$ 以上では, DOS は, ほぼ同様の形状を示 している. この時のDOSの形状は, 中段のUPS スペクト ルを良く再現していることが分かる．例えば， $N=8$ のスペ クトル上に示した “a”, “b” で示した構造は, 実際の特定 の分子軌道に対応する訳ではないが，UPS 上で観測された “a”，“b”の構造を良く説明している，最後に，大きなサイ ズの結晶粒を持つ試料, つまり結晶性の高い試料に対する結 果である上段の UPS スペクトルの形状は，中段のものと異 なる. $0.5 \sim 2.5 \mathrm{eV}$ 付近の構造は, 図中で $1 \sim 3$ と記した三 つの構造からなる.これは, 先ほどの会合体のDOS では説 明がつかない. 会合体の分子数が十分に増加して, 結晶性を 持つと，エネルギーバンドが形成されるはずである．そこで,

Fig. 7 に示したバンド計算から求めた DOS の形状と比較し てみる. 図中, 塗りつぶしたスペクトルがバンド計算から得 られたDOSで, 実線は, それを実験結果と比較するため に, 測定のエネルギー分解能等を考慮してエネルギー的に幅 をつけたものである. 図中, 1〜3の構造は, それぞれ, ブ リルアンゾーンの高対称点の平坦なバンド分散に起因するス パイク状の DOS から生じている.この1〜3の構造は, 先 のUPS スペクトルの $1 \sim 3$ の構造に良く対応している.こ の結果は, 結晶性の $\mathrm{Ph}_{2}$-IDPL の固体薄膜中では, 確かに $0.5 \mathrm{eV}$ を越える大きなエネルギー分散を持つエネルギーバ ンド構造が実現していることを示している。 また，Fig. 7 の 結果は, $\mathrm{Ph}_{2}$-IDPLの単量体から出発し, 共有結合を介し て，その会合体，またその結晶と系が大きく発達していった 時に，単分子の分子軌道が，どのように変化し，エネルギー バンド構造が形成されてゆくかを示している。これは， $\mathrm{Ph}_{2}$-IDPL と言う特有の系における現象と言うよりも, 一般 的に単量体から分子数が増加するに従って, どのようにエネ ルギーバンド構造が形成されてゆくか，を明瞭に示している ものであり, 興味深い.

$\mathrm{Ph}_{2}$-IDPL のもう一つの特筆すべき性質は, エネルギーギ ヤップが非常に小さいと言う点である. Fig. 8 亿非晶質の $\mathrm{Ph}_{2}$-IDPL 膜の UPS-IPES（逆光電子分光）スペクトルを 示す。これは, エネルギーギャップ周辺の占有, 非占有 DOSを直接示すものである。これから見積もられる $\mathrm{Ph}_{2}-$ IDPL のエネルギーギャップは約 $1.2 \mathrm{eV}$ であり， $E \mathrm{~F}$ はちょ うどエネルギーギャップの中心付近に位置する. 一般的な有 機半導体分子では $2 \mathrm{eV}$ を下回るものはほとんどない15).さ らに, ガス中蒸発法を用いて得られた結晶性の $\mathrm{Ph}_{2}-\mathrm{IDPL}$ 薄膜のエネルギーギャップは $1 \mathrm{eV}$ 以下に狭をる。産総研の 近松らは, 非晶質の $\mathrm{Ph}_{2}$-IDPL 膜を用いて電界効果トラン ジスタを作製し, $\mathrm{Ph}_{2}$-IDPL 単層で双極性を示す事を報告し ている (Fig. 9 $)^{12)}$. 彼らは, ソース電極にも, ドレイン電 極にも $\mathrm{Au}$ を用いているが，上述のように $\mathrm{Ph}_{2}$-IDPL のエネ ルギーギャップが非常に小さい上に， $E_{\mathrm{F}}$ がちょうどエネル 


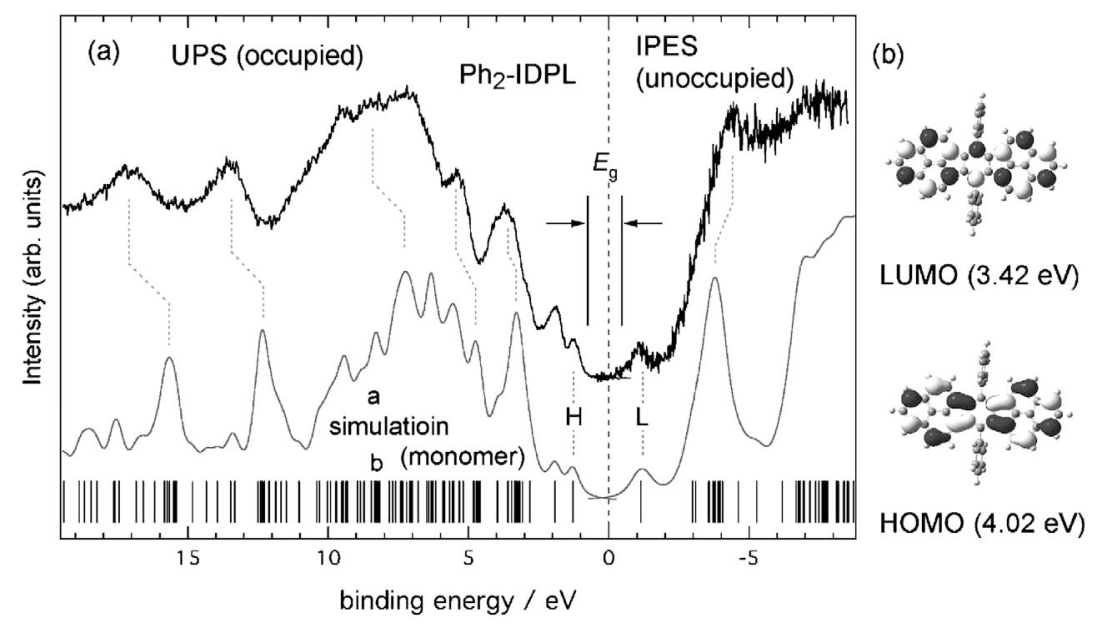

Fig. 8 (a) UPS and IPES spectra of $\mathrm{Ph}_{2}$-IDPL amorphous film on graphite $(d=7.5 \mathrm{~nm})^{13)}$. Bottom axis: binding energy with respect to $\mathrm{E}_{\mathrm{F}}$. Simulated spectra labeled "a" were obtained from the MOs labeled "b", which were calculated by the DFT method for Ph $\mathrm{h}_{2}-\mathrm{IDPL}$ monomer. Energies for simulated spectra were individually shifted to reproduce the observed spectra. $\mathrm{H}$ and $\mathrm{L}$ indicate the calculated HOMO and LUMO. (b) Simulated LUMO and HOMO with their calculated orbital energies.

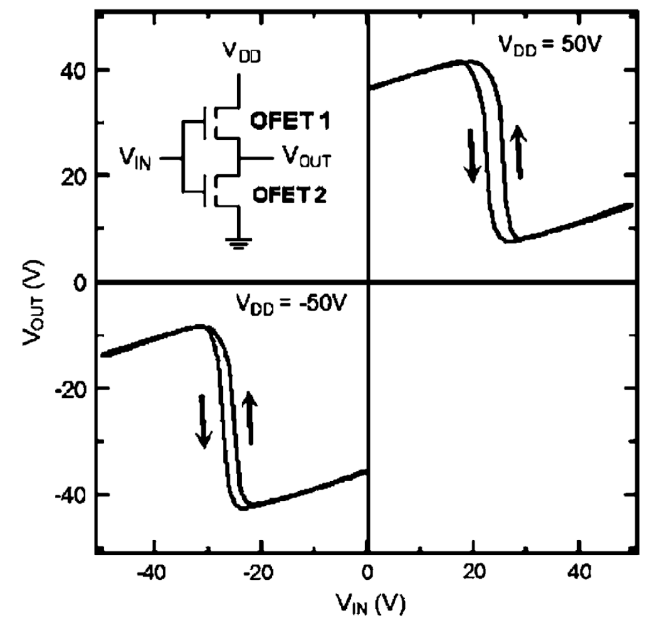

Fig. 9 Transfer characteristics of the CMOS-like inverter of $\mathrm{Ph}_{2}$-IDPL amorphous film at supply voltages $\left(V_{\mathrm{DD}}\right)$ of +50 and $-50 \mathrm{~V}$. The results are cited from the literature ${ }^{12)}$. The inset shows the circuit configuration.

ギーギャップの中心付近に位置するために，電子，正孔とも に注入障壁が小さく, $\mathrm{Ph}_{2}$-IDPL 薄膜単層で双極性を示すと 解釈できる. 近松らの報告によると, 得られた移動度は $\mu=$ $10^{-3} \mathrm{~cm}^{2} / \mathrm{Vs}$ 程度であるが, 電子と正孔ともにバランスのと れた双極性を示している.

単層で安定した双極性 FET を作製できることは，応用の 面から興味深い。そのため, 現在, 我々はガス中蒸発法によ って作製した $\mathrm{Ph}_{2}-$ IDPL 結晶性薄膜を用いて, 移動度の向 上を図っている．結晶性薄膜を用いることで，バンド伝導を 利用した高移動度化, また, 非晶質膜よりも小さいエネル ギーギャップによる注入障壁の低減が見込まれる.

\section{BDTDA 結晶性薄膜の作製と電子状態}

BDTDA は非ケクレ型の disjoint 型ビラジカルである99.

Fig. 10 にDFT 計算による BDTDA の HOMO，LUMO を 示した. BDTDA は二つの dithiadiazolylラジカル分子を連

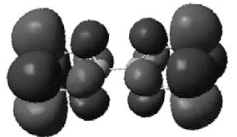

HOMO

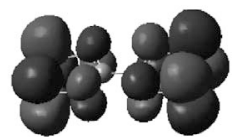

LUMO
Fig. 10 Simulated molecular orbitals for the HOMO and the LUMO of BDTDA.

結した形をしている，BDTDAの HOMO, LUMO はラジカ ル部位に位置しており, ラジカル由来のスピン間の交換相互 作用は弱い。これは, 先に述べたように disjoint 型ビラジカ ルの特徵である. BDTDA は, $\mathrm{Ph}_{2}$-IDPL とは異なり分子の 二量体化を防ぐような立体障害を持たないため, 薄膜中に抒 いても容易に二量体を形成する. Fig. 11 にBDTDA 分子 と，その固体薄膜のUPS スペクトルを示した．スペクトル a は気相のBDTDA のスペクトルであり，孤立したBDTDA 分子のDOSを示している。一方，スペクトルfは BDTDA 薄膜のスペクトルであり, a とは大きく異なること が分かる．この違いを理解するために，b〜eに DFT 計算に よるDOS とバンド計算によるDOSを示した。まず，bは BDTDA 分子の DOS であり, それぞれのピークや構造の位 置を含めてaのスペクトルを良く説明することが分かる。一 方で, c の DOS は BDTDA の二量体に対する結果である.

一見, e のスペクトルを良く再現するように思われるが, 両 者には本質的な違いがある. $\mathrm{f}$ のスペクトルの $1 \sim 2 \mathrm{eV}$ 程度 のピークは, *で示した肩構造があり, 左右非対称な形状を しているが，cのスペクトルの対応するピークは 2 つの分子 軌道からなり, 左右対称な形状をしている. この違いは, 薄 膜中では BDTDA 二量体の間にも軌道間相互作用が存在し ていることを示している. d は, ふたつの BDTDA二量体 を結晶構造と同様の位置関係に置いた場合のDOSである.

二量体間には軌道間相互作用がはたらき, cで, 先ほどの ピークを形成している $2 つ 9$ 分子軌道は, 左右非対称に 4 つの分子軌道に分裂する. その結果, *で示すような肩構造 


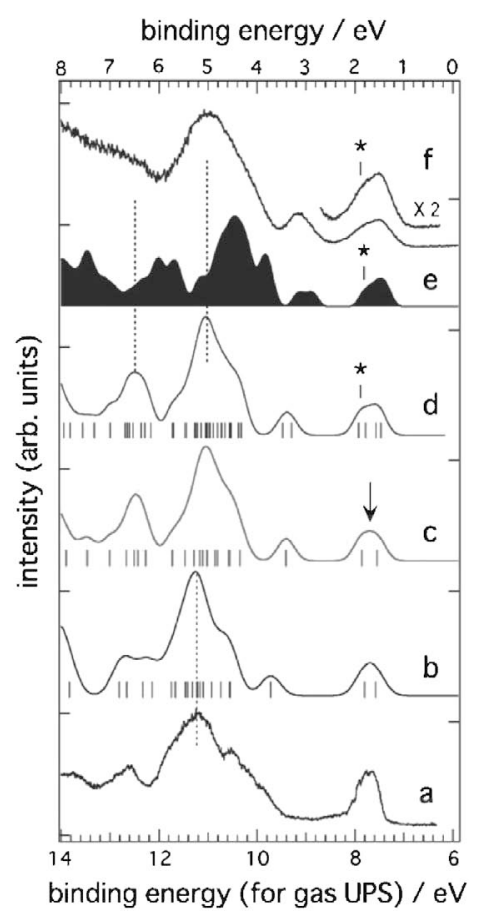

Fig. 11 UPS spectra of BDTDA in the gas phase (a) and thin film (f). Calculated MOs (vertical bars) and simulated UPS spectra for the BDTDA monomer in the triplet ground state (b), the BDTDA dimer (c) and the stacked dimers (d). The filled spectra in (e) represent 50 calculated DOS for the onedimensional stacked dimer chain along the a-axis. Simulated UPS spectra were obtained by convoluting calculated MOs with a Gaussian function at the experimental resolution. Top and bottom axes represent binding energy for thin film (f) and gas-phase (a) spectra, respectively. Origins of the top and bottom axes are the $E_{\mathrm{F}}$ of the substrate and the vacuum level, respectively. Energy axes for simulated MOs and UPS spectra are individually shifted to reproduce the observed spectra. Asterisks indicate the shoulder structure observed in the thin film spectrum (f), calculated DOS (e) and simulated spectrum for stacked dimers (d).

が出現する，この肩構造は, BDTDA二量体を無限に一次 元的に配列した系に対するバンド計算（e）から求めた DOS にも現れることが分かる．この肩構造を伴ったDOS の形状 は，fの実際の UPS スペクトルを良く再現することができ る。この結果は, 薄膜中では BDTDA は二量体を形成した 上でスタックし，さらに二量体間の相互作用が存在すること を示している. Fig. 12 にDFT 計算による BDTDA二量体 の HOMO, LUMO を示した. 分子平面の四隅に位置する $\mathrm{S}$ の位置で $\pi$ 軌道が二量体の外側へ大きく張り出しているの がわかる.この傾向は, 特に LUMO に抢いて強い。このよ うに，二量体の $\pi$ 軌道が空間的に広がっているため，他の ビラジカルやラジカル分子と異なり, BDTDA は二量体を 形成したあとも，二量体間の結合が生じると考えられる.

Fig. 13(a)には, 名古屋大学の岩崎らによって報告された $\mathrm{Au}, \mathrm{ITO}$ (ガラス), $\mathrm{Si}$ 基板上に作製した BDTDA 膜の XRD の結果を示した ${ }^{10)}$. ぞの基板の場合でも $2 \theta=14.0^{\circ}$, $28.1^{\circ}$ に BDTDA 結晶の (100), (200)回折が強く現れ, Fig. 13(b)のように, 基板の表面に垂直な方向に BDTDA 二量体 がスタックした結晶性の薄膜が成長していることが分かる.

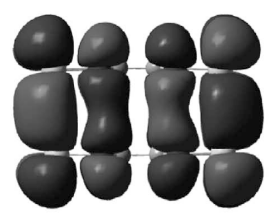

HOMO

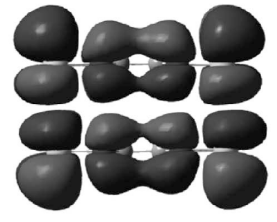

LUMO
Fig. 12 Simulated molecular orbitals for the HOMO and the LUMO of BDTDA dimer.

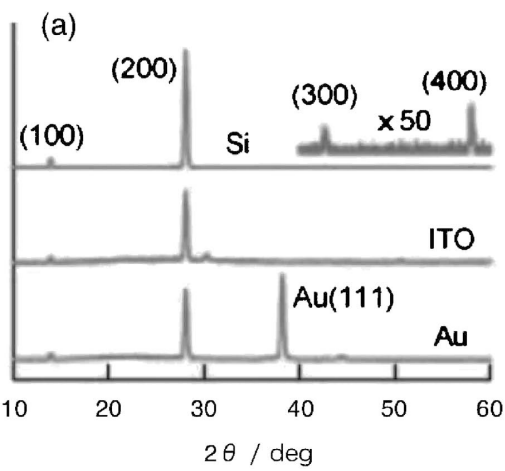

(b)

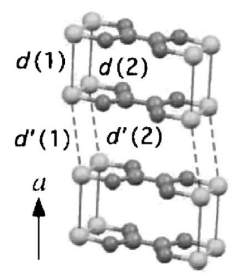

Fig. 13 (a) Out-of-plane XRD patterns of BDTDA thin films on $\mathrm{Si}$, ITO, and Au cited from the literature ${ }^{10)}$. (b) Stacked dimers structure parallel to the a-axis.

ここで得られた格子定数は $0.63 \mathrm{~nm}$ であり, 結晶のバルクの $\mathrm{a}$ 軸方向の格子定数 $0.629 \mathrm{~nm}$ と良く一致する. 興味深いの は, BDTDA は $\mathrm{Ph}_{2}-\mathrm{IDPL}$ とは異なり, ぞのような基板上 に製膜した場合でも, ガス中蒸発やアニールなど, 特殊な処 理を全く施すことなく十分高い結晶性の薄膜が得られる点で ある、これは, BDTDAは, 固体中で，二量体のスタック 方向のみではなく, 分子面と平行な方向の異なる BDTDA 分子で $\mathrm{S}-\mathrm{N}$ 間の二次元的な相互作用が存在するためだと考 えられる。つまり, BDTDA二量体を構成要素とした 3 次 元的な相互作用が，薄膜中で凝集を助け，結晶化しやすくし ていると思われる。

Fig. 14に角度分解光電子分光 (ARUPS) によって得ら れた $\mathrm{GeS}(100)$ 表面上に作製した膜厚 $30 \mathrm{~nm}$ の BDTDA の結 晶性薄膜のバンド分散の様子を示す. ARUPS は垂直放出の 配置を用いて, BDTDA 結晶の a 軸方向のバンド分散を観 測している. 図中, 実線で示したのはBDTDA二量体を一 次元的に並べた系に対するバンド計算の結果である.バンド 計算で得られている $\mathrm{a}_{1}, \mathrm{a}_{2}$ の二枚のバンドが実際に

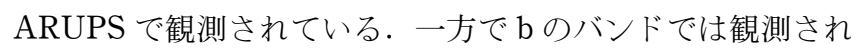
たバンド分散はバンド計算のものに比べて狭い， $a_{1}, a_{2}$ の二 枚のバンドに注目すれば, BDTDA 薄膜中には, 基板と垂 直な方向に $0.3 \sim 0.5 \mathrm{eV}$ に及ぶ大きなバンド分散を持つバン ド伝導が実現していることになる. 実際に, BDTDA 薄膜 では, Fig. 15に示したように, 基板の推移直方向, つまり BDTDA 結晶の a 軸方向に電極を配置した素子は, 高い $\mathrm{ON} / \mathrm{OFF}$ 比の光伝導性を示し, バイアスを印可しない場合 でも, 光起電力が生じた. 通常の有機半導体固体の場合, 光 吸収で生じた励起子の解離が難しいために, 単層で光起電力 を示す例は少ないが, BDTDAの場合は, Fig. 14で示した 


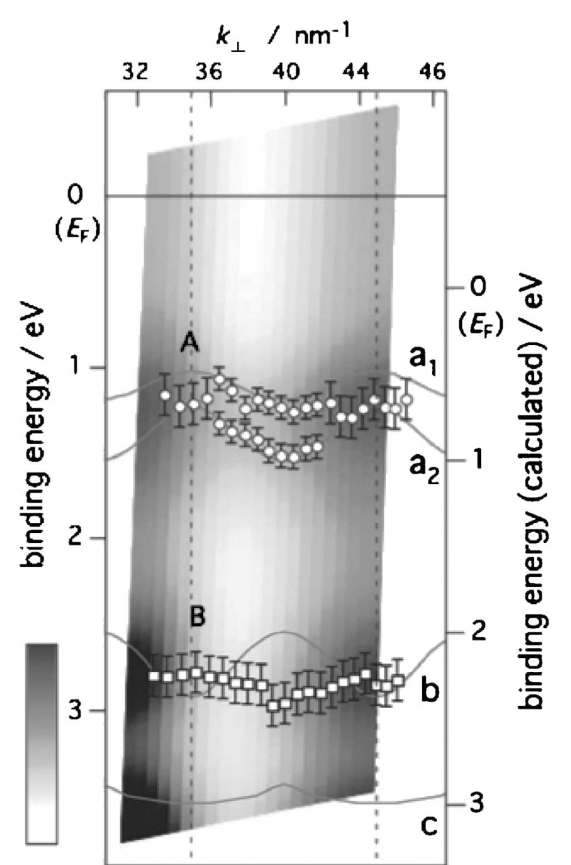

Fig. 14 A UPS intensity plot of BDTDA film. The abscissa and ordinate represent momentum perpendicular to film surface normal, and binding energy with respect to $E_{\mathrm{F}}$, respectively. Dotted lines indicate the boundaries of the Brillouin zone in the extended zone scheme ${ }^{16)}$.

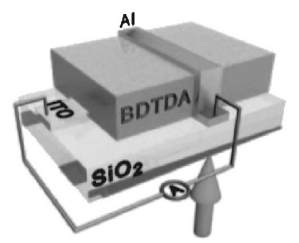

Fig. 15 Schematic of the structure of the ITO/BDTDA/Al sandwich cell reported in the literature ${ }^{10)}$.

ように分散の大きなバンド伝導実現している事から, 光励起 状態において, 特に電子が非局在化しやすく, 電荷分離しや すい状態にあることが一因と考えられる.

BDTDA が優れている点は，二量体を形成することによ って安定化する点, そして，Sを持つために，その二量体の 分子軌道が空間的に広がり, 二量体間にも軌道間相互作用が 生じる点である. 二量体間の結合は, 光励起された状態な ぞ, 励起状態が空間的に広がる要因となることから, 単層で の光起電力の発現なぞ, 興味深い現象を引き起こしている.

\section{5. まと め}

ペンタセンや，各種フタロシアニンなど，代表的な有機半 導体分子は, 弱い分散力を主な凝集力として固体薄膜を作る ため, 結晶性を高めることが難しい。一方で，有機ビラジカ ル分子は，軌道相互作用を介して，非常に強い分子間引力を 持つために，製膜時に，うまくその分子間引力が活かされる 状況にあれば，自己組織化的に結晶性の高い薄膜を作ること ができる，そして，本稿では，そうして得られた結晶性薄膜 中では, 分子鎖が形成され, 無機半導体的なエネルギーバン ド伝導機構が実現していることを示した，比較的簡単に, ぞ
のような基板の上にも高伝導度を持つ有機半導体薄膜を作製 すことができることは，応用の面から非常に有用である。ま た, 本稿では, $\mathrm{Ph}_{2}-$ IDPL の結果について示したように, 有 機ビラジカル分子は, 微小ギャップ半導体としても興味深い 材料である. 単に微小ギャップと言う特性の久に着目するの であれば, これまでにも幾つかの電荷移動錯体結晶を薄膜化 して用いる方法が検討されてきた. しかし, 電荷移動錯体は 基本的に多成分系であり, 化学量論比を保ち, 再現性の高い 薄膜を作製するのは容易ではない, 一方, 有機ビラジカル分 子は, 真空蒸着やガス中蒸発法と言った比較的簡単な方法に よって, しかも単層で作製することができるため, 一度に大 量に作製する事ができる上に再現性は高く, 応用の面から非 常に有用であると考元らる.

今後, これらの有機ビラジカル分子の特異な性質を活か し, 有機ビラジカル分子が新しい有機エレクトロニクス材料 として着目され，応用研究がより発展する事を期待している。

\section{〔文献〕}

1) H. Inokuchi, Y. Harada and Y. Maruyama: Bull. Chem. Soc. Jpn., 35 (1962) 1559.

2) K. Awaga, T. Sugano and M. Kinoshita: Bull. Chem. Soc. Jpn., 58 (1985) 1886.

3) X. Chi, M. E. Itkis, B. O. Patrick, T. M. Barclay, R. W. Reed, R. T. Oakley, A. W. Cordes and R. C. Haddon: Science, 121 (1999) 10395.

4) T. M. Barclay, A. W. Cordes, R. C. Haddon, M. E. Itkis, R. T. Oakley, R. W. Reed and H. Zhang: J. Am. Chem. Soc., 121 (1999) 969.

5) T. M. Barclay, A. W. Cordes, R. H. de Laat, J. D. Goddard, R. C. Haddon, D. Y. Jeter, R. C. Mawhinney, R. T. Oakley, T. T. M. Palstra, G. W. Patenaude, R. W. Reed and N. P. C. Westwood: J. Am. Chem. Soc., 119 (1997) 2633.

6) J. L. Brusso, K. Cvrkalj, A. A. Leitch, R. T. Oakley, R. W. Reed and C. M. Robertson: J. Am. Chem. Soc., 128 (2006) 15080.

7) L. Beer, J.L.Brusso, A. W. Cordes, R. C. Haddon, M. E. Itkis, K. Kirschbaum, D. S. MacGregor, R. T. Oakley, A. A. Pinkerton and R. W. Reed: J. Am. Chem. Soc., 124 (2002) 9498.

8) T. Kubo, A. Shimizu, M. Sakamoto, M. Uruichi, K. Yakushi, M. Nakano, D. Shiomi, K. Sato, T. Takui, Y. Morita and K. Nakasuji: Angew. Chem. Int. Ed., 44 (2005) 6564.

9) C. D. Bryan, A. W. Cordes, J. D. Goddard, R. C. Haddon, R. G. Hicks, C. D. MacKinnon, R. C. Mawhinney, R. T. Oakley, T. T. M. Palstra and A. S. Perel: J. Am. Chem. Soc., 118 (1996) 330.

10) A. Iwasaki, L. Hu, R. Suizu, K. Nomura, H. Yoshikawa, Y. Noda, K. Kanai, Y. Ouchi, K. Seki and H. Ito: Angew. Chem. Int. Ed., 48 (2009) 4022.

11) Y. C. Cheng, R. Silbey, D. A. da Silva Filho, J. P. Calbert, J. Cornil and J. L. Brédas: J. Chem. Phys., 118 (2003) 3764.

12) M. Chikamatsu, T. Mikami, J. Chisaka, Y. Yoshida, R. Azumi, K. Yase, A. Shimizu, T. Kubo, Y. Morita and K. Nakasuji: Appl. Phys. Lett., 91 (2007) 043506.

13) K. Kanai, Y. Noda, K. Kato, T. Kubo, K. Iketaki, A. Shimizu, Y. Ouchi, K. Nakasuji and K. Seki: Phys. Chem. Chem. Phys., 12 (2010) 12570.

14) K. Iketaki, K. Kanai, A. Shimizu, T. Kubo, Z. H. Wang, Y. Ouchi, Y. Morita, K. Nakasuji and K. Seki: J. Phys. Chem. C, 113 (2009) 1515.

15) A. Kahn, N. Koch and W. Gao: J. Polym. Sci. B: Polym. Phys., 41 (2003) 2529.

16) K. Kanai, H. Yoshida, Y. Noda, A. Iwasaki, R. Suizu, J. Tsutumi, H. Imabayashi, Y. Ouchi, N. Sato, K. Seki and K. Awaga: Phys. Chem. Chem. Phys., 11 (2009) 11432. 